\title{
PRINCIPAIS ETIOLOGIAS E ASPECTOS CLÍNICOS DAS LESÕES CERVICAIS NÃO CARIOSAS
}

Flavia Fratucci de VALÕES; Rafael Torres BRUM

A abrasão, erosão, abfração, e suas possíveis interações, têm sido consideradas como as principais causas das lesões cervicais dos dentes. Este trabalho é uma revisão de literatura a respeito das etiologias e principais aspectos clínicos destas lesões. A abrasão é considerada como a perda de substância dental por ação mecânica (Pereira, J.C.,1995). As lesões envolvem geralmente vários dentes, possuindo margens agudas e bem definidas (Baratieri, L.N. et al., 2001). A erosão é descrita como o processo gradual de destruição da superfície dental por meio de substâncias ácidas, sem envolvimento bacteriano. Pode ser classificada como extrínseca, intrínseca ou idiopática (Imfeld, T., 1996). Algumas características são encontradas na maioria dos casos de erosão: perda do brilho normal dos dentes; exposição de dentina nas superfícies vestibulares, palatais/linguais; incisivos encurtados e com relação largura/comprimento desproporcional; concavidades dentinárias nas superfícies oclusais ou incisais, etc. A abfração tem como etiologia a ação de forças tensionais (Lee e Eakle, 1984; LEE, H.E. et al., 2002). Apresenta-se clinicamente como um defeito em forma de cunha na região cervical do dente. A prevenção e o tratamento adequados das lesões nãocariosas dependem do conhecimento dos fatores causais e das características clínicas de cada tipo lesão. 